\title{
Will a New Motorway Bridge Affect Avifauna of the Danube in Bratislava?
}

\author{
Miloslav Mišík \\ Tilgnerova 14, Bratislava, 84105, Slovakia; misik.milo@gmail.com
}

ABSTRACT: The aim of my study was to monitor avifauna on the seepage canal of the Danube River reservoir and the nearby Danubian arm prior to the motorway bridge construction near Bratislava in Slovakia. The monitored locations were the Protected Landscape Area and Important Bird Area (IBA) River Danube floodplains and the Site of Community Importance (SCI) Biskupice floodplains. Identification and counting of all visually and acoustically recorded species were performed using line transect method at monthly intervals and the species dominance and frequency were calculated. Altogether, 83 species of birds were recorded with 71 on the seepage canal and 57 on the Danube arm. During our visits, 9 of the 16 criteria water bird species for Danube floodplains IBA were recorded. The number of water bird species prevailed over other species from January until the nesting period when migratory species, including numerous song-birds, arrived. Wintering and migrating gradually stoppped starting in April. The rarest species within my surveys was the Caspian tern (Hydroprogne caspia). The observation of the rare Anas acuta $\times$ Netta rufina hybrid was most surprising.

KEYWORDS: Ecology; Avifauna; Danube River; Slovakia; Monitoring; Motorway Construction; Bird Migration.

\section{Introduction}

The subject of this work was a survey of both the left-side seepage canal of the Danube River reservoir and the nearby parallel western arm of the Danube to obtain phenological data on bird occurrences during the migration, wintering, and breeding seasons of 2017-2018. This subject was chosen as the new D4 motorway construction was planned for 20182020 and obtaining avifauna data for the situation before, during, and after motorway construction is important for understanding the motorway's environmental impact. This location is not regularly monitored, so there is no recent data. The Hrušov water reservoir on the Danube River is the largest wintering and migratory stopover for water birds in Slovakia. Additionally, the Protected Landscape Area and IBA - River Danube floodplains and the SCI with educational path Biskupice floodplains are located next to a large refinery as well as within protected areas of the NATURA 2000 network. ${ }^{1}$ The Gajc and Kopáč Island Nature reserves are situated here as well. ${ }^{2}$ Bird occurrence data with nesting categories can be found in the Slovak avifauna database. ${ }^{3}$ The avifauna data from the IBA River Dunabe, focusing on criteria species, were summarized within the Special Protection Areas in Slovakia. ${ }^{4}$ Researchers have also previously studied the wintering of Netta rufina on the Danube River. ${ }^{5}$

The main goals of the work were

- to research avifauna on the pre-defined areas before the motorway bridge construction (2017), focusing on ecology of water bird species;

- to monitor breeding, migrating and wintering species, especially criteria species for this area indicating their ecosozological status;
- to compare actual data from the seepage canal, with the older data and to find out differences within the water bird assemblages;

- to obtain data for the on-going projects "New Atlas of Birds of Slovakia" and also for "Winter Water Bird Counting" and record them to the ornithology web-database AVES Symfony;

- to perform a survey during the construction (2018) with to evaluate changes in taxa composition.

Two impacted water ecosystems of the artificial canal and the natural Danube river arm have not been regularly monitored. The related literature concerns large-scale areas and the main Danube River channel.

\section{Results}

In 2017, 83 bird species were recorded with 71 species on the seepage canal and 57 species on the Danube arm (Annex 1). Sixteen criteria species including water birds as a group represent the criteria birds for Danube floodplains IBA. ${ }^{4}$ During our visits, nine citerita species were observed (Annex 1, Annex 2).

\section{Seasonal dynamics of recorded species :}

Since both sites have been monitored at monthly intervals during 2017, both the individual numbers and species numbers changed over time. There were more water bird species compared to other species from January until the nesting period when migratory species, including songbirds, arrived. Wintering and migrating species of ducks, geese, and swans gradually began leaving in April.

On the first visit in January there were 29 bird species in the seepage canal with 18 being water species. The ratio of water birds to other species remained constant during the second visit. In March, during the third visit, there were only five recorded species, an $80 \%$ decrease as well as the lowest recorded 
species total for the entire year (Figure 1). A similar trend was observed in the case of aquatic species numbers. They occurred in the hundreds in January and February but in March the numbers decreased an order of magnitude lower. In the Danube arm, however, the highest number of aquatic species, thirteen, was recorded in March (Figure 1). These changes in species numbers was most likely caused by the Danube arm freezing over in January and February forcing the water birds to move to the non-freezing seepage canal. In March, after the Danube arm surface had melted, the water birds returned. During spring and summer the numbers of individuals in both localities fluctuated only in the tens; in the seepage canal the numbers rose to 110 during October. At the end of the summer, the decrease in the Hrušov reservoir water level was also reflected on the Danube arm by formation of shallows as suitable feeding and resting places for water birds. Consequently, the number of individuals rose to 131 in September and remained in the hundreds for the rest of the year. By December, water bird species did not dominate anymore (total of nine species) while song birds became the dominant bird type beginning in May, with 25 of 35 species on the seepage canal and 20 species of 26 on the Danube arm. The ratio of song bird individuals was much higher around the canal (480 out of 566) than in the arm area (189 out of 232) compared to other groups. I especially appreciate the rare migrant or wintering Turdus iliacus which impressed with high numbers ( 8 in November alongside the canal and 14 in December on the oxbow arem).

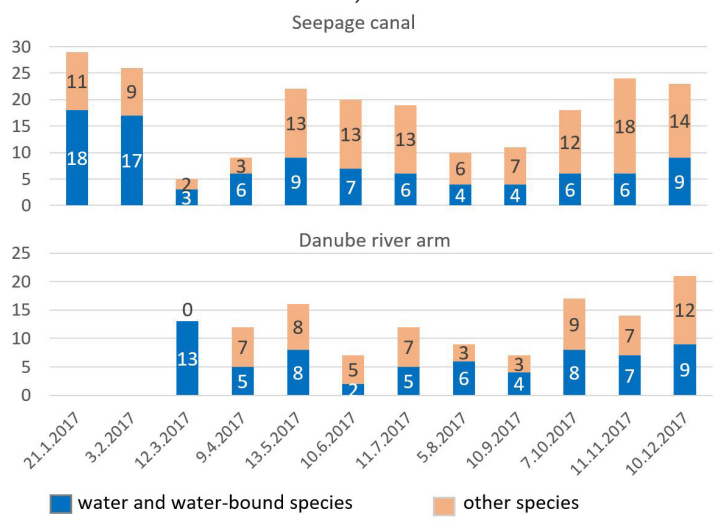

Figure 1: Seasonal dynamics of recorded species in monitored sites in 2017.

\section{Comparison of water avifauna in monitored sites:}

The greatest difference in occurrence of water birds between the arm and the canal was found in the group of waders (Figure 2). They prevailed over other water bird species on the Danube arm (7 species totalling 45 individuals versus 3 species totalling 19 individuals on the canal) that had more appropriate conditions like food and habitat. I found Larus ridibundus, L. michahellis, Actitis hypoleucos, and Sterna hirundo from the water bird group. Hydroprogne caspia, commonly known as the Caspian tern, was the rarest species in my surveys and recorded on April 9. Observing the rare crossbreed of Anas acuta $\times$ Netta rufina was the most surprising experience in the March visit to the Danube arm.

Anas platyrbynchos was the only constant ( $\geq 75 \%$ ), regular aquatic species for both monitored sites as well as the most dominant species (> 5\%). Cygnus olor and Aythya fuligula were also dominant species for both locations. Aythya fuligula is the criteria species for the Special Protection Area (SPA) because of its high numbers of wintering individuals.

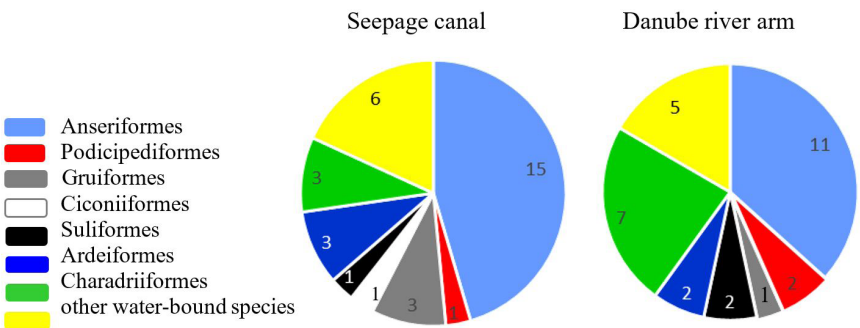

Figure 2: Ratio of numbers of species in monitored locations.

Occurrence and nesting of dominant species and other interesting species on the seepage canal:

In addition to the above-mentioned species, Fulica atra and Tachybaptus ruficollis were dominant species on the seepage canal where there was high amounts of vegetation. Anas platyrhynchos was present year-round and was observed to nest with chicks. Cygnus olor was also omnipresent except from July - September, but nesting has not yet been documented. Aythya fuligula was observed in high numbers in January-FebruaryDecember. Two summer occurrences were recorded. Although it was not proved during this project, the possibility of nesting arose after observing one pair in June and four individuals in July. Fulica atra and Tachybaptus ruficollis appeared irregularly and formed groups in the migration and winter months. Gallinula chloropus was another species with all-year-round occurrence. Its nesting was demonstrated by an observation of several 1-2 day-old chicks in May. Netta rufina was a rare species with 4 individuals recorded in February. In May, a couple with the prossibiltiy of nesting was observed. In June, the suspicion increased when only a male was found on the site, nervously flying over the entire length of the canal. Despite our expectations, chicks were not found and thus nesting was not proven. The endangered Aythya nyroca was the rarest migratory species found on the seepage canal. Seven individuals were observed in October, a relatively high number. Based on our records of migratory and wintering species, ${ }^{6}$ the location was shown to be suitable for wintering and migratory routes of aquatic birds. Several ducks, namely Anas clypeata, $A$. penelope, A. crecca, A. querquedula, A. Strepera, Aythya ferina, $A$. nyroca, Bucephala clangula and Fulica atra, were recorded on the canal in 2017 but were not found in 2018. This is most likely because the Danube arm did not freeze in 2018.

\section{Criteria species recorded at localities:}

In addition to aquatic birds, nesting species such as Sterna birundo belong to the nine criteria species for the River Danube floodplains IBA. Three flying specimens of Haliaeetus albicilla were registered in December. It is a significant breed$\mathrm{er}^{4}$ and a subject of protection as their numbers are expected to be negatively impacted by the D4 motorway construction. ${ }^{7}$ The other criteria species were ducks - nesting species Anas strepera, A. querquedula, Aythia fuligula, A. ferina, Netta rufina, and migrating and wintering species Bucephala clangula, Mer 
gellus albellus and Mergus merganser. The last species mentioned is also classified as a rare nesting bird in Slovakia.

\section{Comparison of the results with older data:}

When studying 2006 records from the seepage canal, ${ }^{3}$ a similarity between the species composition of water birds with our data was found but others were not confirmed during our survey. For example, the occurrence of Actitis bypoleucos, Mergus merganser, Mergellus albellus, Microcarbo pygmeus were not found. I think these differences were mainly caused by the length of the monitored stretch. Most of the older data refer to the section from the beginning of the canal to Hamuliakovo village (i.e. almost to the Šmorín part of the Hrušov Reservoir) with large areas for wintering of these species. Our monitored section of the canal is much shorter and covered with trees. Hence it is often neglected by migrating birds. When comparing data on Netta rufina, it was determined that the species was more common in the Šamorín part of the canal than this study's area. The most important finding is the confirmation of the data about appropriate wintering places in the adjacent sections of the Danube River within the reservoir area. $^{5}$

\section{- Conclusion}

As expected, rare bird species appeared during migration and in the winter months when the number of individuals was the highest (in January it was up to 951 birds on the seepage canal). Of the predominant water species, the conditions were optimal for only five of them (constant or dominant) and for one proven nesting species. On the Danube river arm, the reason for an earlier increase in the number of water birds (both species and individuals) in autumn is that migrating species prefer a larger water surface. They move to the canal only when the arm is frozen. This was particularly obvious when several duck species were recorded on the canal in 2017 but not found here in 2018. The arm did not freeze in 2018 so ducks did not move there. The larger water area of the Danube arm is also more suitable for gull species. Wooden debris and shallows make them an appropriate shelter for resting or catching fish. The rare observation of the Caspian tern that flew over the spring migration is of high faunistical value, as well as the presence of 7 individuals of Aythya nyroca. I also recorded the rare Anas acuta and Netta rufina hybrid.

While during the coldest months (January to March) water and water-bound birds dominated, the rest of the year speciesdiverse song birds predominanted. They were particularly numerous near the seepage canal in a typical biotope of the old floodplain of the natural reserves of Kopáč Island and Gajc, the area being strongly affected by the planned motorway construction. In the coming years it will be important to monitor the changes in the surrounding natural environments. In nearby locations I have found a number of baseline data on the species composition and abundance of avifauna present which I can use toward future comparison with the conditions during and after the motorway construction. Upon refinement from bird song recordings I also plan to focus on acoustic calls by song birds. They could still be overlooked because of my ignorance. At the same time, I will concentrate on key months during the wintering, autumn migration and nesting periods to ensure species abundance. I would like to monitor the nesting time as long as possible according to the proposed method of nesting birds counting, in the second half of May and June. ${ }^{13}$

\section{- Methods}

For the purpose of the avifauna monitoring on pre-defined locations the following methods were applied:

- mapping of avifauna once a month during the 2017 calendar year;

- $\quad$ identification and counting of all visually and acoustically recorded species in the specified transect (line transect method), calculation of the species dominance and frequency; a photo-documentation of the species and their habitats;

- comparison of the results obtained with available literature, websites, and data from ornithological databases; evaluation of monitoring results and graphical interpretation of the processed results; recording all observations into the ornithological database AVES Symfony, recording rare observations into the Birding Slovakia database;

- from 2018 additional surveys of wintering, nesting, and autumn migration.

\section{Description of the monitored area:}

The monitored area (N48 $\left.5^{\prime} 46.27^{\prime \prime}, \mathrm{E} 17^{\circ} 9^{\prime} 21.94^{\prime \prime}\right)$ lies in Central Europe in the cadastre area of Bratislava about $4 \mathrm{~km}$ south of the Slovnaft oil refinery (Figure 3). Both monitored sections are included in protected areas of different extent and levels. Both areas are affected by the planned construction of the motorway bridge as shown in Figure 4. The area of interest hides the preserved floodplain forests and oxbows. On the Kopác Island there is a forest grove with special vegetation such as common reed and birch. The investigated seepage canal is $10 \mathrm{~m}$ wide. It is an artificially created canal situated alongside the reservoir dike and the floodplain forests with the purpose to capture the leaked water from the water reservoir (Figure 5). The canal was monitored in the section designated from its beginning to the first gate (2.85 km long). Bank vegetation of the canal is represented mostly by reed, young birch, poplar, and various scrubs. It is a relatively shallow and clean seepage canal with a gravel and muddy bottom which also affects the occurrence of individual bird species.

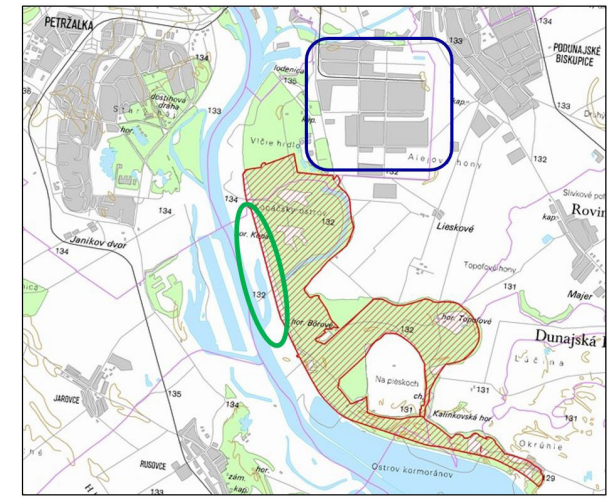

Figure 3: Designation of the Site of Community Importance SKUEV0295 Biskupické luhy (red-shaded); monitored area depicted in a green elipse; Slovnaft refinery depicted in a blue square. 


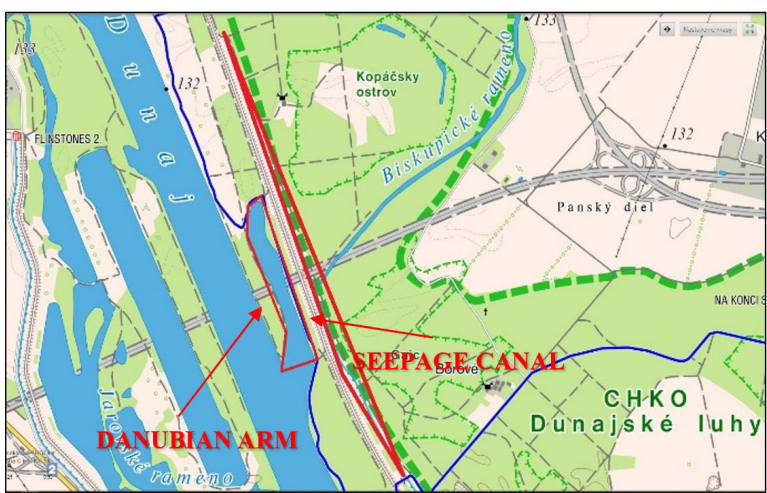

Figure 4: The monitored area of the Danube river arm and a seepage canal (red borders) with Protected Landscape Area River Danube floodplains (CHKO Dunajské luhy) and two Nature reserves Gajc and Kopáč Island. The sketch of the bridge construction across the monitored area is depicted in gray.
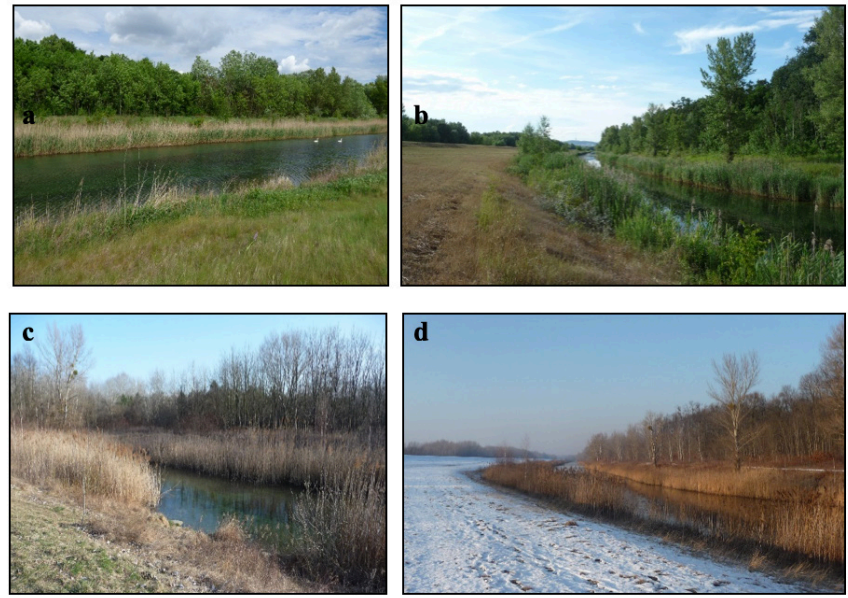

Figure 5: Seepage canal in spring (a), summer (b), autumn (c) and winter (d). Photos by M- Mišík, 2017.

The investigated parallel Danube arm, $50-150 \mathrm{~m}$ in width and $1.3 \mathrm{~km}$ in length, is surrounded mainly by the poplar vegetation of the floodplain forest. The arm has a muddy bottom and the banks are overgrown with reeds (Figure 6). In the mouth of the arm the driftwood and stones provide suitable rest places for some birds.

\section{Mapping method:}

The seepage canal was visited every month during 2017 where all the observed or heard species of birds were recorded and counted inside the $100 \mathrm{~m}$ wide and $2.85 \mathrm{~km}$ long stripe (from the beginning / $48^{\circ} 5^{\prime} 53.28^{\prime \prime} \mathrm{N}, 17^{\circ} 9^{\prime} 2.13^{\prime \prime} \mathrm{E}$ to the first lock at the Mini Vyza Buffet / 48 $44^{\prime} 27.10^{\prime \prime N}, 17^{\circ} 9^{\prime} 58.06 " \mathrm{E}$ ) with the monitored surface area of $0.285 \mathrm{~km}^{2}$. The parallel Danube arm at a distance of about $150 \mathrm{~m}$ was investigated as well (Figure 6). Due to the frozen water surface of this Danube arm at the beginning of the year, it was monitored from March to December at monthly intervals. The mapped area of $0.17 \mathrm{~km}^{2}$ corresponded to its length passing along the adjacent forest and fishing path and to the width between this path and the opposite bank of the arm. The same method was used in 2018 during the period of wintering (January - February), nesting (April - June) and autumn migration (September November).
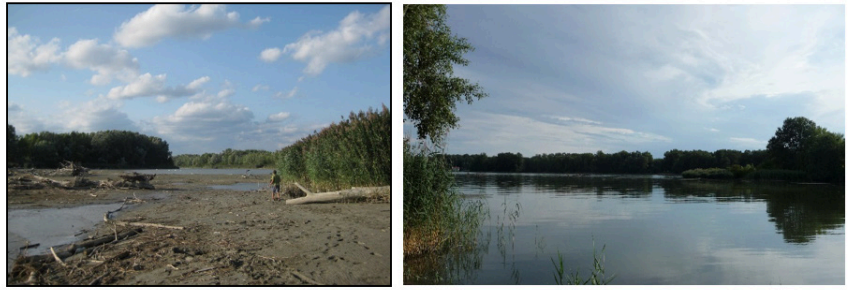

Figure 6: Danube river arm during low water (left) and standard water level (right).Photos by M. Mišík, 2017.

\section{Method of evaluation:}

Species were identified according to a 2016 paper. ${ }^{9}$ The recorded species were divided into wintering species (occurring from December to February), nesting species (including species with year-round occurrence) and migratory species (both spring and autumnal migrators). ${ }^{6}$

The ecosozological status assessment of each species was based on the Red List of Birds of Slovakia. ${ }^{8}$ The text classifies bird species into the categories of extinction risk, endangered, vulnerable and nearly threatened and on the IUCN Red Lists (for Europe and World). ${ }^{10}$ Important Bird Area was declared in the given territory ${ }^{11}$ for the protection of criteria species listed according to 2015 paper. $^{4}$ The frequency and dominance of species was calculated; ${ }^{12}$ those with a frequency above $75 \%$ are considered to be constant year-round in an area. The dominance of water and water-bound species was determined where the dominant species had a dominance above 5\%. Preliminary changes in a species composition were evaluated on the basis of the number of recorded species in 2018 compared to 2017 data.

\section{Acknowledgement}

I acknowledge my parents for their ongoing support during my field observations and in my research at home as well as Ms. Iveta Piršelová at Tilgnerova High School for her encouragement in each my endeavors. Special thanks to Jozef Ridzon for the inspiration by the selection of theme and to Soňa Nuhličcková and Ján Svetlík for their expert advice. I wish to also thank my English teacher Danka Mestická for her help with translating and Blanka Lehotská for her guidance in the preparation of the paper.

\section{References}

1. http://datazone.birdlife.org/home

2. http://uzemia.enviroportal.sk/

3. http://aves.vtaky.sk/index/

4. Karaska, D.; Trnka, A.; Krištín, A.; Ridzoň, J.

Chránené vtáčie územia Slovenska [Special Protection

Areas in Slovakia]. Štátna ochrana prírody SR,

Banská Bystrica, 2015; 380 pp.

5. Rác, P.; Ridzoň, J.; Slabeyová, K. Zimovanie hrdzavky potápavej (Netta rufina) na Dunaji [Wintering of Red-crested Pochard (Netta rufina) on the Danube River]. Tichodroma 2009, 21, 106-107.

6. Danko, Š.; Darolová, A.; Krištín, A. Rozšírenie vtákov na Slovensku [Birds Distribution in Slovakia]. VEDA, Bratislava, 2002; 683 pp.

7. Proposal of Compensation Measures, National Motorway Company/NDS, 2014

8. Demko, M.; Krištín, A.; Pačenovský, S. Červený zoznam vtákov Slovenska [Red List of Birds of Slovakia]. SOS/BirdLife Slovensko, 2014; 52 pp. 
ijhighschoolresearch.org

9. Svensson, L.; Mullarney, K.; Zetterstrom, D. Ptáci Evropy, Severní Afriky a Blízkeho Východu [Birds of Europe, North Africa and Middle East]. Ševčík, 2016; 447 pp.

10. https://www.iucnredlist.org/

11. Nuhličková, S. (ed.) Chránime vtáctvo v územiach NATURA 2000 [We protect birds in teritories of NATURA 2000]. SOS/BirdLife Slovensko, 2014; 40 pp.

12. Janda, J; Řepa, P. Metody kvantitatívního výzkumu v ornitologii [Methods of quantitative research in ornithology]. Státné zemědělské nakladatelství, Praha, 1986; $158 \mathrm{pp}$.

13. Slovenská ornitologická spoločnost' /BirdLife Slovensko. Metodika systematického dlhodobého monitoringu výberových druhov vtákov v chránených vtáčích územiach. [Methods of systematic lonterm monitoring of criteria bird species in Important Bird Areas]. Štátna ochrana prírody SR, Banská Bystrica, 2013

\section{Author}

Miloslav Mišík is a student at Tilgnerova High School. His way of life has always been focused on ornithology and zoology. He spends all his free time observing and studying birds and plans to devote his future to this field of research.
ANNEX 1: Table of recorded species of birds in monitored area.

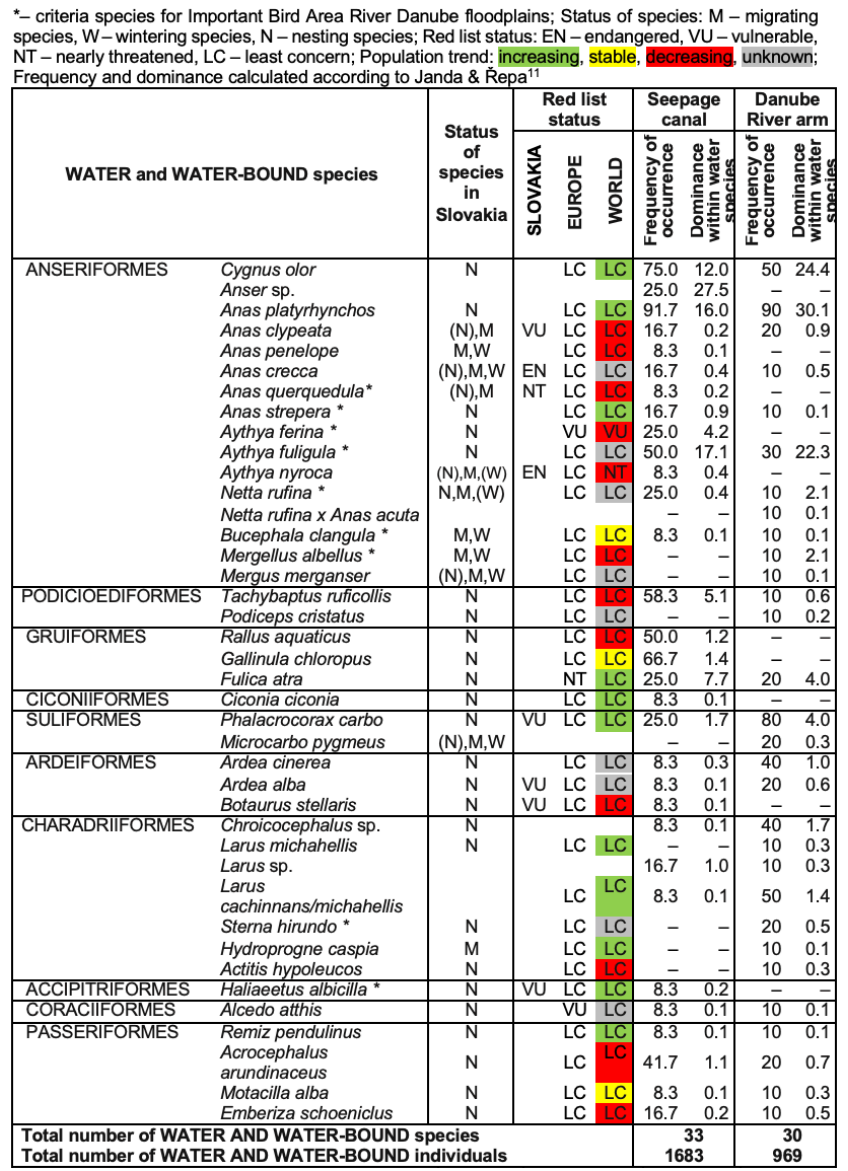

\begin{tabular}{|c|c|c|c|c|c|c|c|}
\hline & & $\begin{array}{l}\text { species } \\
\text { in } \\
\text { Slovakia }\end{array}$ & $\begin{array}{l}\overleftarrow{x} \\
\frac{x}{x} \\
0 \\
\text { ळ }\end{array}$ & 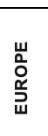 & 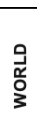 & 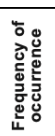 & 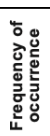 \\
\hline \multirow{2}{*}{$\begin{array}{l}\text { ACIPITRIFORMES } \\
\text { and } \\
\text { FALCONIFORMES }\end{array}$} & \multirow{2}{*}{$\begin{array}{l}\text { Buteo buteo } \\
\text { Accipiter nisus } \\
\text { Falco tinnunculus }\end{array}$} & $N$ & & LC & LC & 41.7 & 30 \\
\hline & & $\begin{array}{l}\mathrm{N} \\
\mathrm{N}\end{array}$ & & $\begin{array}{l}\text { LC } \\
\text { LC }\end{array}$ & LC & $\begin{array}{r}16.7 \\
8.3\end{array}$ & $\begin{array}{l}20 \\
-\end{array}$ \\
\hline BUCEROTIFORMES & Upupa epops & $\mathrm{N}, \mathrm{M}$ & NT & $\mathrm{LC}$ & & 8.3 & - \\
\hline GALLIFORMES & Phasianus colchicus & $\mathrm{N}$ & & LC & $\angle C$ & 25.0 & - \\
\hline \multirow[t]{2}{*}{ COLUMBIFORMES } & Columba palumbus & $\mathrm{N}$ & & LC & LC & 50.0 & 10 \\
\hline & Streptopelia turtur & $\mathrm{N}, \mathrm{M}$ & & vu & & 16.7 & 10 \\
\hline APODIFORMES & Apus apus & $\mathrm{N}, \mathrm{M}$ & NT & $\mathrm{LC}$ & LC & 16.7 & - \\
\hline \multirow{3}{*}{$\begin{array}{l}\text { CUCULIFORMSS } \\
\text { PICIFORMES }\end{array}$} & Cuculus canorus & $\mathrm{N}, \mathrm{M}$ & & $\frac{L C}{L C}$ & & 16.7 & 20 \\
\hline & Dendrocopos major & $\mathrm{N}$ & & LC & LC & 50.0 & 40 \\
\hline & $\begin{array}{l}\text { Picus viridis } \\
\text { Dryocopus martius }\end{array}$ & $\stackrel{N}{N}$ & & $\begin{array}{l}\text { LC } \\
\text { LC }\end{array}$ & $\begin{array}{l}\text { LC } \\
\text { LC }\end{array}$ & $\begin{array}{r}8.3 \\
25.0\end{array}$ & $\overline{20}$ \\
\hline \multirow{29}{*}{ PASSERIFORMES } & Oriolus oriolus & $\mathrm{N}, \mathrm{M}$ & & $\frac{L C}{L C}$ & LC & - & $\frac{20}{10}$ \\
\hline & Lanius collurio & $\mathrm{N}, \mathrm{M}$ & & LC I & & 16.7 & - \\
\hline & Garrulus glandarius & N & & LC & LC & 50.0 & 20 \\
\hline & Corvus frugilegus & $\mathrm{N}$ & & LC I & & 16.7 & - \\
\hline & Corvus comix & $\mathrm{N}$ & & & & 50.0 & 40 \\
\hline & Cyanistes caeruleus & $\mathrm{N}$ & & LC & LC & 66.7 & 50 \\
\hline & Parus major & $\mathrm{N}$ & & LC & LC & 83.3 & 80 \\
\hline & Hirundo rustica & $\mathrm{N}, \mathrm{M}$ & vu & LC & & 25.0 & - \\
\hline & Aegithalos caudatus & $\mathrm{N}$ & & LC & LC & 25.0 & 20 \\
\hline & $\begin{array}{l}\text { Sitta europaea } \\
\text { S }\end{array}$ & $\mathrm{N}$ & & LC & LC & 8.3 & 10 \\
\hline & Phylloscopus collybita & $\mathrm{N}, \mathrm{M}$ & & & LC & 33.3 & 30 \\
\hline & Phylloscopus trochilus & $\mathrm{N}, \mathrm{M}$ & & LC & & & 10 \\
\hline & Troglodytes troglodytes & $\mathrm{N}$ & & LC & LC & 25.0 & 10 \\
\hline & Regulus regulus & $\mathrm{N}$ & & LC & 20 & - & 10 \\
\hline & Sturnus vulgaris & $\mathrm{N}, \mathrm{M}, \mathrm{W}$ & & LC & & 8.3 & 10 \\
\hline & Turdus merula & & & LC & LC & 75.0 & 60 \\
\hline & Turdus iliacus & (N),M,W & & NT & $L$ & 8.3 & 10 \\
\hline & Turdus pilaris & $\mathrm{N}$ & & LC & LC & 16.7 & - \\
\hline & Turdus philomelos & $\mathrm{N}, \mathrm{M},(\mathrm{W})$ & & LC & LC & 8.3 & - \\
\hline & Phoenicurus ochruros & $\mathrm{N}, \mathrm{M},(\mathrm{W})$ & & LC & LC & 8.3 & - \\
\hline & Erithacus rubecula & $\mathrm{N}$ & & LC & LC & 8.3 & 10 \\
\hline & Passer montanus & $\mathrm{N}$ & & LC & LC & 8.3 & - \\
\hline & Fringilla coelebs & $\mathrm{N}$ & & LC & LC & 33.3 & 40 \\
\hline & Fringilla montifringilla & $\mathrm{M}, \mathrm{W}$ & & LC & & 8.3 & \\
\hline & Pyrrhula pyrrhula & $\mathrm{N}$ & NT & LC & LC & 16.7 & 10 \\
\hline & $\begin{array}{l}\text { Coccothraustes } \\
\text { coccothraustes }\end{array}$ & $N$ & & LC & LC & 16.7 & 10 \\
\hline & Chloris chloris & $\mathrm{N}$ & & & LC & 8.3 & 10 \\
\hline & Carduelis carduelis & $\mathrm{N}$ & & LC & LC & 50.0 & 10 \\
\hline & Emberiza citrinella & $\mathrm{N}$ & & LC & & 50.0 & - \\
\hline \multicolumn{6}{|c|}{$\begin{array}{l}\text { Total number of OTHER species } \\
\text { Total number of OTHER individuals }\end{array}$} & $\begin{array}{r}38 \\
566\end{array}$ & $\begin{array}{r}27 \\
210\end{array}$ \\
\hline \multirow{2}{*}{\multicolumn{6}{|c|}{$\begin{array}{l}\text { TOTAL NUMBER of SPECIES } \\
\text { TOTAL NUMBER of INDIVIDUALS }\end{array}$}} & 71 & 57 \\
\hline & & & & & & 2249 & 1179 \\
\hline
\end{tabular}

ANNEX 2: Photo gallery (Photos by M. Mišík, 2017).
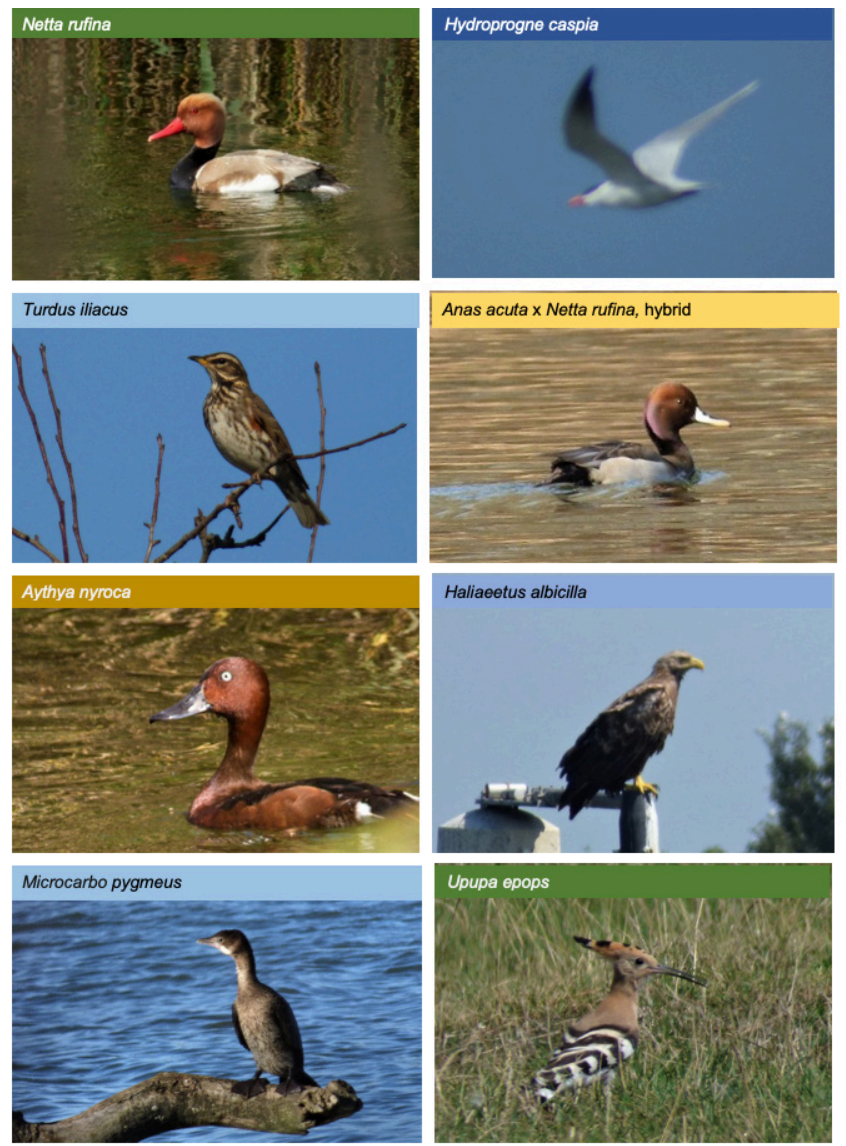